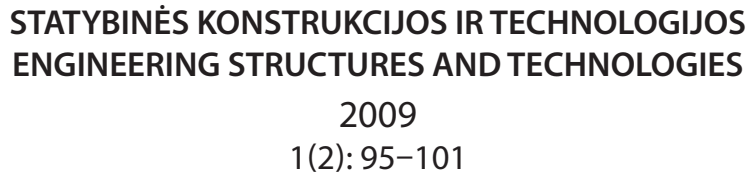

\title{
INVESTIGATING THE PROTECTIVE PROPERTIES OF CONCRETE CONTAINING ASH FROM COAL COMBUSTION IN A FLUIDIZED BED
}

\author{
Katarzyna Domagała ${ }^{1}$, Adam Zybura ${ }^{2}$ \\ Faculty of Civil Engineering, The Silesian University of Technology, \\ ul. Akademicka 5, 44-100 Gliwice, Poland \\ E-mails: ${ }^{1}$ katarzyna.domagala@polsl.pl; ${ }^{2} a d a m . z y b u r a @ p o l s l . p l$
}

Received 3103 2009; accepted 18042009

\begin{abstract}
The article reports the results of research on the protective properties of concrete with the addition of ash from hard coal combustion in a fluidized bed at a power plant in Katowice. Research was carried out on concentrated water extracts from disintegrated concrete using a polarization technique. The results were compared with those obtained in a similar way from concrete extracts without additives and with criteria including the delimiting values of the parameters of the electrochemical process. The results have shown that concrete incorporating $15 \%$ and $30 \%$ ash as cement replacement correctly protect reinforcement against corrosion.
\end{abstract}

Keywords: protective properties of concrete, concrete supplement, cement replacement materials, ash from fluidized bed combustion, reinforcement corrosion, polarization curves, corrosion current, corrosion potential.

\section{Introduction}

The power industry in Poland is based mainly on solid fuels - mostly hard coal. Combustion products constitute waste and their management is an important economic and technical problem (Coufal 1999). So far, combustion practice has formed, among other things, fly ash, which is a useful mineral supplement to concrete. Research conducted over the last few years has shown that fly ash has pozzolanic properties and that it can be taken into account in concrete formulas as a binder component (Jiang et al. 1999; Fu et al. 2002). The use of fly ash in concrete technology is included in standards (EN 450: 2005, EN 206-1: 2000).

With the present desire to limit the emission of harmful compounds into the atmosphere, power stations and heat and power stations are undergoing modernization that consists of installing fluidized beds, in which the process of fuel combustion runs at temperature lowered to $850^{\circ} \mathrm{C}$. As a result of this solution, the emission of nitric and sulphur oxides is lowered. However, ashes from combustion in a fluidized bed are different from those obtained in a conventional way, especially in relation to a phase type. Although concrete with the addition of fly ashes is characterized by good compressive strength and reinforcement protective proprieties against corrosion, these positive properties cannot be directly obtained with the inclusion of ashes from fluidized bed combustion. Hence, currently, experimental work is being undertaken the aim of which is to qualify the conditions permitting the general supplementation of ashes from a fluidized bed to the production of the structural types of concrete $(\mathrm{Pa}-$ cewska et al. 2002; Giergiczny, Pużak 2008; Łagosz et al. 2008; Domagała, Zybura 2009).

The aim of this paper is to show that replacing cement with ash from fluidized bed combustion furnace does not cause deterioration in the protective properties of concrete in regard to steel reinforcement.

The linear polarization method was conducted to define the basic parameters of the corrosive process. The ability of concrete in the passivation of the steel surface was determined in concentrated water extracts 
from concrete modelling porous liquid. Concrete contained ash from the hard coal combustion power station in Katowice. The ash was applied in two proportions $-15 \%$ and $30 \%$ by weight of cement, whereas water to binder ratio (together cement and ash) was constant and maintained at 0.55 . The obtained values were compared with the results of analogous measurements conducted in a model solution from reference concrete without additives in water to binder the ratio of 0.55 . Research on three kinds of concrete is considered.

\section{Method and Scope of Investigations}

Research was conducted on steel reinforcement grade BSt 500S (DIN 488-1: 2006) modelling the protective influence of concrete with water solutions. Model solutions reflected conditions occurring in concrete which is not subject to aggressive influences from the environment. Research had an electrochemical character and was conducted using the polarization method in a tree-electrode circuit (Choi 2006; Ha et al. 2007).

Electrochemical measurements were recorded offering three solutions. One solution was taken from concrete free of ashes and the obtained results were used as a reference level. The two remaining solutions were prepared from concrete mixes with the addition of ashes from a fluidized bed.

Water samples were extracted from nine $10 \times 10 \times 10-\mathrm{cm}$ size cubical specimens crumbled after crushing them in a testing machine at a later stage. 3 series of samples were formed including 3 cubes in every series. The individual series of samples were constituted from concrete created according to different formulas, varying ash content and altering the class of Portland cement. The types of concrete were marked applying the symbols:

- A0 - ash-free reference mix,

- A15K - with $15 \%$ ash content,

- A30K - with 30\% ash content.
All types of concrete were based on a mix of natural fine aggregates of $0-2 \mathrm{~mm}$ river sand, a coarse aggregate of 2-8 $\mathrm{mm}$ gravel and high early durability cement. The plasticizers BASF Liquol BV18 and BASF Glenium SKY591 (www.basf-admixtures.pl) were used for preparing concrete. The composition of concrete mixes is given in Table 1.

The embedded samples were kept in moulds for three days. After removal from the moulds, the samples were described and placed for the period of 25 days in a climatic chamber at a temperature of $20^{\circ} \mathrm{C}$ and relative moisture $\geq 95 \%$.

\section{Technique and Procedures of Research}

The vacuum concentration method was used to prepare model solutions (Wieczorek 1993). The concentration process imitates conditions present in the concrete pores under the influence of humidity and temperature changes causing a periodical increase in the concentration or thinning of the liquid adsorbed by pores and a change in the chemical constitution of the solution connected with new equilibrium states between the solid and liquid phases of concrete. The specific relation between water and hardened paste corresponds to the actual humidity of concrete while the aggregate is treated as inert material. The preparation of the model solution is derived from the vaporization of water extract induced by intensive pressure on ground and hardened concrete which is in continuous contact with the dissolved solid phase. The concentration of the solution was adjusted proportionally to the humidity of concrete accepting that in average, the working conditions of reinforced concrete constructions makes about $5 \%$ of its mass. It is estimated that all lixiviate solutions from concrete must be concentrated 3.4 times.

In preparing water extracts, every sample of crumbled concrete was sifted through a $0.25 \mathrm{~mm}$ sieve placed in a container adding distilled water by weight in proportions 1:1. The thick solution was stirred every

Table 1. Composition of concrete mixes and compressive strength of concrete at 28 days

\begin{tabular}{|c|c|c|c|c|c|c|c|c|c|}
\hline \multirow{2}{*}{ Concrete } & \multirow{2}{*}{$\begin{array}{l}\text { Compressive } \\
\text { strength }[\mathrm{MPa}]\end{array}$} & \multirow{2}{*}{$\begin{array}{l}\text { Water-binder } \\
\text { ratio }\end{array}$} & \multicolumn{7}{|c|}{ Materials $\left[\mathrm{kg} / \mathrm{m}^{3}\right]$} \\
\hline & & & Cement & & Fluidized ash & Water & Aggregate & BV18 & SKY591 \\
\hline A0 & 41.2 & 0.55 & CEM I 42.5R & 320 & - & 176 & 1865 & 2.9 & 1.0 \\
\hline A15K & 32.8 & 0.55 & CEM I 32.5R & 272 & 48 & 176 & 1857 & 2.9 & 1.8 \\
\hline $\mathrm{A} 30 \mathrm{~K}$ & 41.5 & 0.55 & CEM I 32.5R & 224 & 96 & 176 & 1847 & 2.9 & 2.9 \\
\hline
\end{tabular}


few hours for one full day. Later, it was trickled through a filter of average thickness. Trickling was aided by low pressure in a suction flask joined to a vacuum pump. Then, water extract was concentrated in a rotary vacuum evaporator (see Fig. 1).

a)

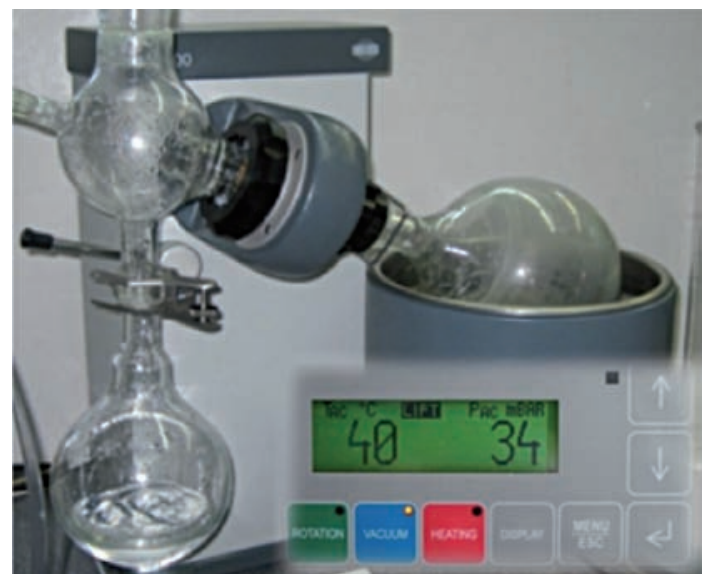

b)

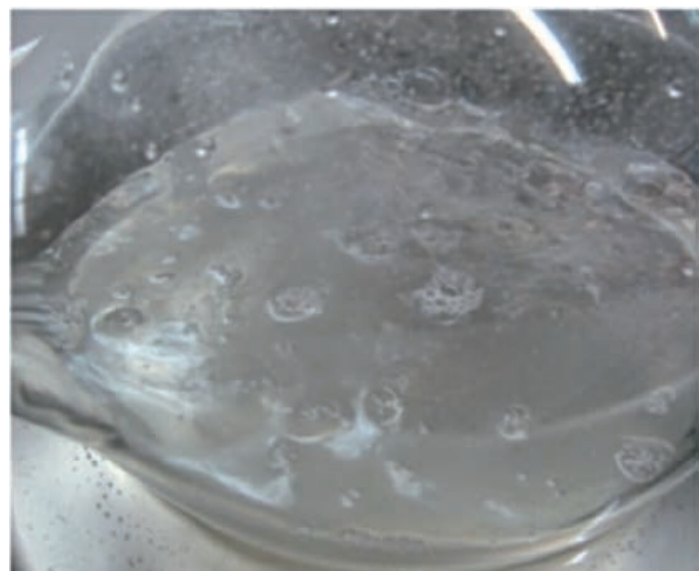

Fig. 1. The method of concentrating model pore liquid in a rotary vacuum evaporator: a) laboratory stand, b) solution boiling at room temperature

In the vacuum evaporator, the pressure was lowered to $34 \mathrm{hPa}$. Such conditions made it possible to bring concentrated liquid to the boiling point at a temperature of about $27^{\circ} \mathrm{C}$. Vaporizing was helped by a radiator that accelerated steam condensation and intensified the process. Because boiling solution causes a drop in its temperature, the flask containing the model pore liquid was immersed in a water bath the temperature of which was about $10^{\circ} \mathrm{C}$ higher than that of the solution inside the flask. From every crushed cube, the sample of $200 \mathrm{ml}$ of concentrated extract was obtained for research on the protective proprieties of concrete.

Electrochemical tests were conducted applying the polarization method in a tree-electrode circuit according to the scheme shown in Fig. 2.

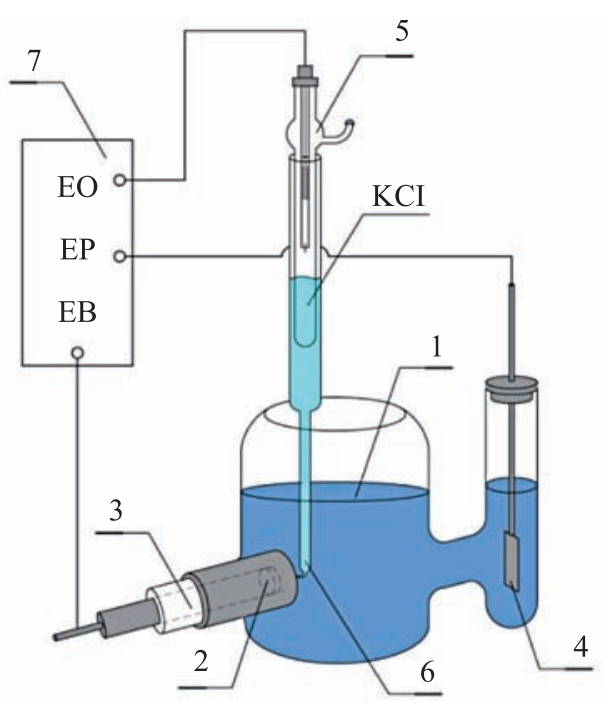

Fig. 2. The scheme of apparatus for research on the protective properties of model pore liquid

Model pore solution 1 was placed in an electrochemical vessel while steel sample 2 lay in holder 3 . In the electrochemical vessel, there was an auxiliary electrode 4 in the form of a platinum-covered titanic plate as well as reference silver-silver chloride electrode 5 together with Eugin's capillary tube 6. Eugin's capillary tube protected against the occurrence of diffusive potential between two electrode solutions. The sample of reinforcing steel 2 (working electrode) was made in the form of a rod of $10 \mathrm{~mm}$ diameter and $5 \mathrm{~mm}$ thickness. The active surface of the working electrode was polished, degreased with acetone and dried. Spur handle 3 assured the working electrode in a surface area of $0.35 \mathrm{~cm}^{2}$. Measurements were made using computer controlled potentiostat 7 supplied by Gamry Instruments Inc. featuring a PC/300 card serving the application DC105 for direct current analysis.

After establishing the value of stationary potential, polarization was begun changing the potential value at a rate of $0.25 \mathrm{mV} / \mathrm{s}$. Every series of measurements consisted of three concentrated model solutions as well as of three independently produced samples reinforcing steel. Analogical measurements obtained from model solutions with concrete containing ash from brown coal combustion in a fluidized bed are reported in our earlier studies (Domagala, Zybura 2009).

Moreover, prior to every electrochemical analysis, a measurement of the $p H$ value of the model solution was executed. This procedure was conducted employing the Mettler Toledo $\mathrm{pH}$-meter with the added measuring electrode dipped in a container filled with water solution from the above analysed concrete. After the $p H$ value stabilised, the reading of $\mathrm{pH}$-meter was noted. 


\section{Test Results}

The results of every electrochemical measurement were obtained as a computer printout of the shape of cathodic and anodic polarization curves as well as the value of corrosion potential $E_{c o r r}$ and corrosion current density $i_{\text {corr }}$.

Polarization curves representing the corrosive properties of reinforcement protected with reference concrete A0 are shown in Fig. 3, with concrete A15K in Fig. 4 and with concrete A30K in Fig. 5.

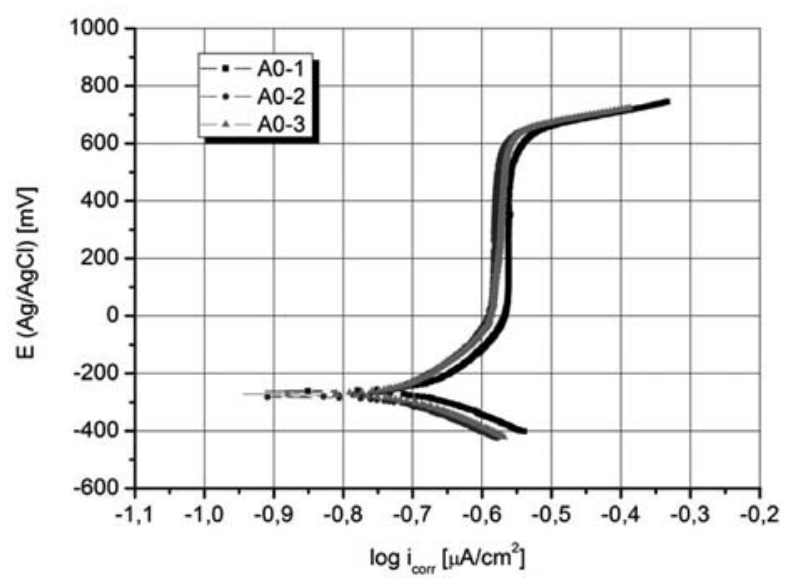

Fig. 3. Polarization curves obtained from model solutions with reference concrete A0

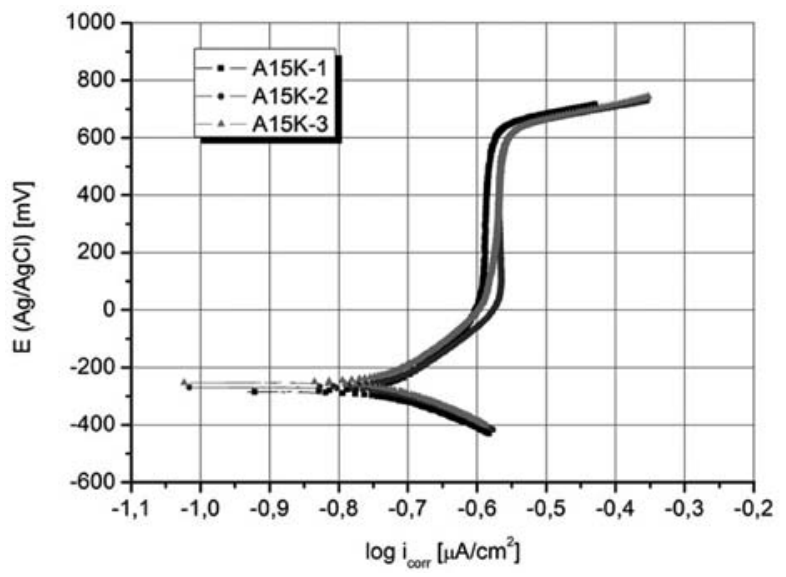

Fig. 4. Polarization curves obtained from model solutions with concrete containing $15 \%$ ash additive - A15K

The analysis of the resulting polarization curves was conducted according to principles presented in Fig. 6.

The value of corrosion current density $i_{\text {corr }}$ and corrosion potential $E_{c o r r}$ are the results of the extrapolation of the straight sections of polarization curves expressed as a logarithmic scale of current density. The abscissa of

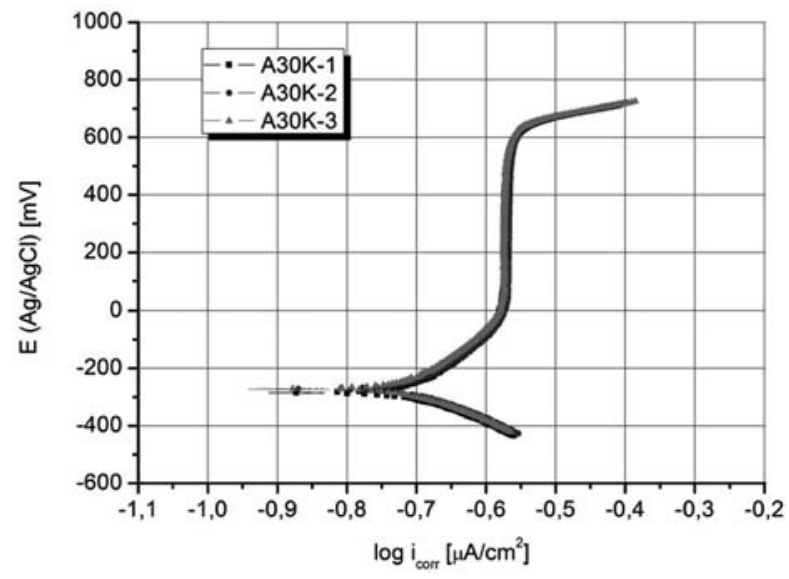

Fig. 5. Polarization curves obtained from model solutions with concrete containing $30 \%$ ash additive - A30K

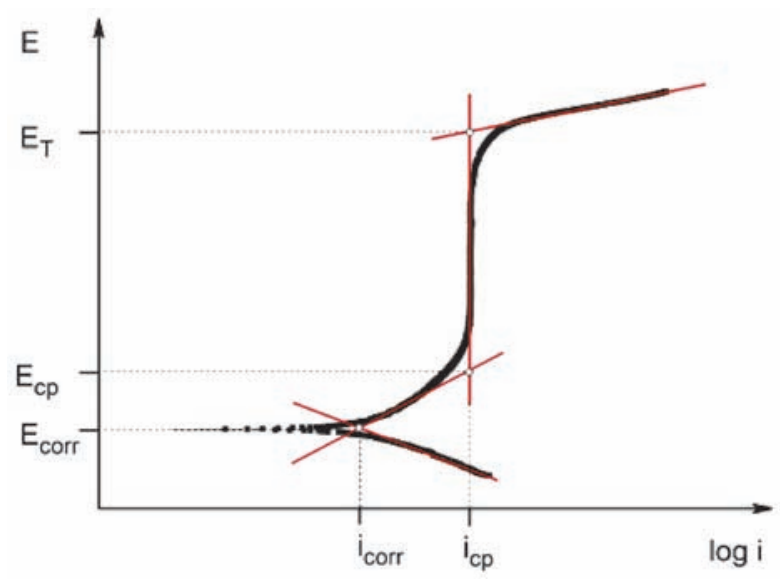

Fig. 6. The principle of determining electrochemical process parameters from the shape of polarization curves

the point of the intersection of both straight sections marks the logarithm of the value of corrosion current density $i_{\text {corr }}$, whereas the ordinate corresponds to the value of corrosion potential $E_{\text {corr }}$. Moreover, on the basis of the shape of polarization curves, the values of critical passivation current density $i_{c p}$, critical passivation potential $E_{c p}$ and transpassivation $E_{T}$ were graphically established.

A summary of the results of the electrochemical research and $p H$ measurements of model solutions are presented in Table 2.

\section{Discussion}

Parameters characterizing the process of reinforcing steel corrosion incurred in model solutions from concrete containing ashes from fluidized combustion were compared with values determined during potentiodynamical measurements in solutions from reference 
Table 2. Statement of electrochemical research results

\begin{tabular}{cccccccc}
\hline \multirow{2}{*}{ Concrete } & \multirow{2}{*}{ Specimen } & & \multicolumn{3}{c}{ Potential $[\mathrm{mV}]$} & \multicolumn{3}{c}{ Current density $\left[\mu \mathrm{A} / \mathrm{cm}^{2}\right]$} \\
\cline { 4 - 8 } & & & $\mathrm{E}_{\text {corr }}$ & $\mathrm{E}_{\mathrm{cp}}$ & $\mathrm{E}_{\mathrm{T}}$ & $\mathrm{i}_{\mathrm{cp}}$ & $\mathrm{i}_{\text {corr }}$ \\
\hline \multirow{3}{*}{$\mathrm{A} 0$} & 1 & 12.53 & -262.2 & -46.4 & 611.5 & 0.27 & 0.19 \\
& 2 & 12.49 & -280.4 & -37.9 & 612.2 & 0.26 & 0.07 \\
& 3 & 12.50 & -271.4 & -31.1 & 615.3 & 0.27 & 0.08 \\
$\mathrm{~A} 15 \mathrm{~K}$ & 1 & 12.41 & -284.2 & -26.6 & 613.3 & 0.26 & 0.07 \\
& 2 & 12.35 & -268.1 & -22.3 & 615.0 & 0.27 & 0.07 \\
& 3 & 12.41 & -251.8 & -0.7 & 611.7 & 0.27 & 0.06 \\
$\mathrm{~A} 30 \mathrm{~K}$ & 1 & 12.53 & -284.9 & -42.0 & 610.2 & 0.27 & 0.10 \\
& 2 & 12.52 & -272.2 & -42.8 & 614.9 & 0.27 & 0.13 \\
\hline
\end{tabular}

concrete (A0) following recommendations for standard (EN 480-14: 2006).

Although standard (EN 480-14: 2006) deems it is sufficient to compare the value of current density $i_{\text {corr }}$ only, however, in the present study, all remaining electrochemical parameters including critical passivation current density $i_{c p}$, corrosion potential $E_{c o r r}$, critical potential of passivation $E_{c p}$ and transpassivation potential $E_{T}$ have been also analysed.

The most recurrent values close to the reference level are characteristically corrosion potential $E_{\text {corr }}$ and transpassivation potential $E_{T}$. The values of critical passivation potential $E_{c p}$ marking the beginning of the passive zone on polarization curves showed a slightly larger variation. The addition of ash from fluidized combustion raised the value of critical passivation potential in comparison with reference concrete (A0), although note that in model solutions from concrete containing a $15 \%$ addition of ash, the value of critical passivation potential was higher than that in solutions from concrete in which $30 \%$ of cement was replaced by ash.

The results of polarization measurements show that on effect of using ash from the fluidized bed as a replacement of $30 \%$ of cement mass imperceptibly enlarged the value of corrosion current $i_{\text {corr }}$ whereas $15 \%$ addition of ashes caused a different tendency influencing on a decrease in corrosion current density. The value of critical passivation current density $i_{c p}$ estimated in individual model solutions were comparable, and therefore it is hard to differentiate individual results on the basis of this parameter.

In respect to differences between the results of measurements obtained in individual solutions, one should stress their small changes that do not show the existence of variable tendencies in relation to those obtained as level reference values. That is why it can be supposed that the exchange of a piece of cement for ash from a fluidized bed did not influence significantly the shape of electrochemical processes at the point of contact with steel-model pore solutions and did not worsen the protective properties of concrete in relation to reinforcement.

In analysing polarization curves, the criteria contained in the monograph (Wieczorek 2002) were also considered. According to the introduced criteria, concrete is characterized with correct protective properties when corrosion potential $E_{\text {corr }}>-378.5 \mathrm{mV}$, corrosion current density $i_{\text {corr }}<1 \mu \mathrm{A} / \mathrm{cm}^{2}$, critical passivation current density $i_{c p}<5 \mu \mathrm{A} / \mathrm{cm}^{2}$ and transpassivation potential $E_{T}>428.5 \mathrm{mV}$. The values of potentials passed originally with regard to the saturated calomel electrode were in reference to the saturated silver-silver chloride electrode applied in research. The results of measurements noted in individual water extracts from concrete also reflect the quoted criteria confirming the statement that the examined steel was in the passive state.

The $p H$ value of concrete covering has a significant influence on the electrochemical state of steel reinforcement. A delimiting value, below which the depassivation of steel surface occurs is recognised as $p H=11.8$ (Wieczorek 2002). The determined $p H$ values of individual model solutions oscillating in the range of 12.35 (A15K-2) $\div 12.53$ (A0-1, A30K-1, A30K-3) give evidence of good protective properties of all studied types of concrete in relation to reinforcing steel.

The results of investigations barring reference to the latest standard (EN 480-14: 2006) were additionally compared with recommendations contained in the currently applicable Polish standard (PN-86/B-01810: 1986] suggesting the following values defined in relation to silver-silver chloride electrode: corrosion potential $E_{\text {corr }}>-328.5 \mathrm{mV}$ and critical passivation potential $E_{c p}>-278.5 \mathrm{mV}$ while transpassivation potential is contained in the range of $428.5<E_{T}<678.5 \mathrm{mV}$. Mo- 
reover, corrosion current density should not exceed $i_{\text {corr }}<15 \mu \mathrm{A} / \mathrm{cm}^{2}$. Electrochemical parameters determined in all analysed model solutions also fulfil the revised criteria of the Polish standard (PN-86/B01810: 1986) which, however, are recognised as somewhat liberal at present (Wieczorek 2002).

\section{Conclusions}

With the aim of managing the waste of products from modernized power stations derived from combustion coal in fluidized beds, a test has been undertaken on the use of ash as cement replacement material in structural concrete. The assessment of protective properties in regard to concrete reinforcement, including ash from the hard coal power station in Katowice, has been conducted using the potentiodynamic method in model solutions. The obtained results have been compared to reference concrete without additives, in accordance with the standard (EN 480-14: 2006) applying additional criteria.

Based on the shape of polarization curves, corresponding to the individual types of concrete, the basic parameters characterizing its ability in the passivation of steel surface have been assessed. Corrosion current density has shown a range from the smallest value $i_{\text {corr }}=0.06 \mu \mathrm{A} / \mathrm{cm}^{2}$ noted in a solution from concrete with $15 \%$ addition of ash (A15K-3) to the largest value $i_{\text {corr }}=0.19 \mu \mathrm{A} / \mathrm{cm}^{2}$ measured in a model liquid from reference concrete (A0-1). These values are considerably smaller than the generally recognised delimiting value $i_{\text {corr }}<1 \mu \mathrm{A} / \mathrm{cm}^{2}$ considered as an indication of the non occurrence of reinforcement steel corrosion (Saraswathy, Song 2006; Wieczorek 2002). The smallest value of critical passivation current density $i_{c p}=0.26 \mu \mathrm{A} / \mathrm{cm}^{2}$ has been estimated in water extract from concrete, including a $15 \%$ addition of ash (A15K1) while the maximum value of critical passivation current density $i_{c p}=0.27 \mu \mathrm{A} / \mathrm{cm}^{2}$ occurred in the solution from reference concrete (A0-1). This parameter similarly testifies to the correct protective properties of all analysed types of concrete (according to (Wieczorek 2002) $i_{c p}<5 \mu \mathrm{A} / \mathrm{cm}^{2}$ ). The most recurrent values, which are close to the level of reference values, have characterized corrosion potential $E_{c o r r}$ and transpassivation potential $E_{T}$ as fulfilling in every case criteria $E_{\text {corr }(\mathrm{Ag} / \mathrm{AgCl})}>-378.5 \mathrm{mV}, \quad E_{T(\mathrm{Ag} / \mathrm{AgCl})}>428.5 \mathrm{mV}$ for the proper protection of reinforcing steel against corrosion (Saraswathy, Song 2006; Wieczorek 2002).

Also giving good evidence for the ability of the individual types of concrete in the passivation of steel rein- forcement surface are the values of $p H=12.35 \div 12.53$ measured in individual model solutions and considerably exceed $p H=11.8$ recognised as a delimiting value below which steel depassivation occurs.

Comparing the results achieved in concentrated water extracts from the types of concrete modified with fly ash additives and from reference concrete and taking into account additional criteria engaging the delimiting values of electrochemical parameters can infer, the use of ashes from hard coal combustion in fluidized beds as cement replacement material did not worsen the protective properties of concrete in relation to steel. Concrete containing $15 \%$ and $30 \%$ of these ashes in relation to the mass of cement protects steel bars against corrosion correctly.

This article was prepared within the framework of Research and Development Project Nr R0401301'Concretes on cements with ash from combustion in fluidized bed'.

\section{References}

Choi, Y.-S.; Kim, J.-G.; Lee, K.-M. 2006. Corrosion behaviour of steel bar embedded in fly ash concrete, Corrosion Science 48: 1733-1745. doi:10.1016/j.corsci.2005.05.019

Coufal, R. 1999. Gospodarcze wykorzystanie w budownictwie ubocznych produktów spalania węgla kamiennego w elektrowniach, in VI Międzynarodowa Konferencja „Popioły z Energetyki" [Economic utilization of by-products from hard coal combustion from power plants in building engineering, $6^{\text {th }}$ International Conference "Ash from power industry"]. Kraków, 95-118.

DIN 488-1: 2006 - Reinforcing steels: Grades, properties, marking.

Domagała, K.; Zybura, A. 2009. Antykorozyjne zabezpieczenie zbrojenia betonem zawierającym popiół z kotłów fluidalnych, Ochrona przed Korozją [Anticorrosive protection of reinforcement with concrete containing ash from a fluidized bed], Protection Against Corrosion 4-5: 205-208.

EN 206-1: 2000 - Concrete. Part 1: Requirements, properties, production and compatibility.

EN 450: 2005 - Fly ash for concrete. Definitions, specifications and criteria of compatibility.

EN 480-14: 2006 - Admixtures for concrete, mortar and grout. Tests methods. Part 14: Determination of the effect on corrosion susceptibility of reinforcing steel by potentiostatic electro-chemical tests.

Fu, X.; Wang, Z.; Tao, W.; Yang, Ch.; Hou, W.; Dong, Y.; Wu, X. 2002. Studies on blended cement with a large amount of fly ash, Cement and Concrete Research 32: 1153-1159. doi:10.1016/S0008-8846(02)00757-3

Giergiczny, Z.; Pużak, T. 2008. Popiół fluidalny a właściwości mieszanki betonowej, in $V$ Konferencja Naukowa "Dni Betonu" [Fluidal fly ash and the properties of fresh concrete mixture, $5^{\text {th }}$ Scientific Conference "The Days of Concrete"].

Ha, T.-H.; Muralidharan, S.; Bae, J.-H.; Ha, Y.-Ch.; Lee, H. G.; Park, K.-W.; Kim, D.-K. 2007. Accelerated short-term techniques to evaluate the corrosion performance of steel in 
fly ash blended concrete, Building and Environment 42: 78-85. doi:10.1016/j.buildenv.2005.08.019

Jiang, L. H.; Lin, B. Y.; Cai, Y. B. 1999. Studies on hydratation in high-volume fly ash concrete binders, ACI Mater. J. 96(6): 703-706.

Łagosz, A.; Małolepszy, J.; Śliwiński, J.; Tracz, T. 2008. Wykorzystanie popiołów fluidalnych jako dodatku mineralnego do betonów, in V Konferencja Naukowa "Dni Betonu" [Utilization of fly-ash from fluidized bed boilers as a mineral additive for concretes, $5^{\text {th }}$ Scientific Conference "The Days of Concrete"].

Pacewska, B.; Bukowska, M.; Wilińska, I.; Swat, M. 2002. Modification of the properties of concrete by a new pozzolan. A waste catalyst from the catalytic process in a fluidized bed, Cement and Concrete Research 32: 145-152. doi:10.1016/S0008-8846(01)00646-9

PN-86/B-01810: 1986 - Antykorozyjne zabezpieczenia w budownictwie. Własności ochronne betonu w stosunku do stali zbrojeniowej. Badania elektrochemiczne [Anticorrosive protection in civil engineering. Protective properties of concrete to reinforcing steel. Electrochemical measurements].

Saraswathy, V.; Song, H.-W. 2006. Electrochemical studies on the corrosion performance of steel embedded in activated fly ash blended concrete, Electrochemica Acta 51: 4601-4611. doi:10.1016/j.electacta.2006.01.005

Wieczorek, G. 1993. Wpływ chlorków na korozję stali zbrojeniowej $w$ betonie, seria: Monografie [Influence of chloride on reinforcing steel corrosion in concrete, structures: Monography]. Warszawa.

Wieczorek, G. 2002. Korozja zbrojenia inicjowana przez chlorki lub karbonatyzację otuliny [Reinforcement corrosion initiated by chloride or carbonatization of concrete covering]. Wrocław.

\section{BETONO SU SKYSTO KURO KROSNYJE SUDEGINTOS ANGLIES PELENAIS APSAUGINIŲ SAVYBIŲ TYRIMAS}

\section{K. Domagała, A. Zybura}

Santrauka. Straipsnyje pateikti betono su Katowice gamykloje skysto kuro krosnyje sudegintos anglies pelenais apsauginių savybių tyrimų rezultatai. Taikant poliarizacijos technologiją buvo tiriamas vandens koncentratas, išskirtas iš suirusio betono. Rezultatai palyginti su panašių tyrimų rezultatais, kai taikant tokią pačią technologiją buvo tiriamas betonas be priemaišų. Rezultatai taip pat buvo palyginti pagal kriterijus, ịvertinančius ribines elektrocheminio proceso parametrų reikšmes. Rezultatai parodè, kad, betone 15 ar 30 proc. cemento pakeitus pelenais, armatūra būna tinkamai apsaugota nuo korozijos.

Reikšminiai žodžiai: apsauginès betono savybès, betono priedai, cementą pakeičiančios medžiagos, skysto kuro krosnyje sudegintos anglies pelenai, armatūros korozija, poliarizacijos kreivès, korozijos srovè, korozijos potencialas.

Adam ZYBURA. DSc, PhD, Professor. Department of Building Structure, The Silesian University of Technology. The author and co-author of 8 monographs, 2 manuals, 94 scientific and technical articles and over 90 papers on domestic and international conferences. Research interests: structural problems of building engineering, durability and protection against corrosion of concrete structures.

Katarzyna DOMAGAŁA. PhD student. Department of Building Structure, The Silesian University of Technology. Research interests: problems of concrete structures durability, especially the protective properties of steel reinforcement embedded in concrete with an addition. 